\title{
"In My Empty Existence I Have Seen It All": On Colin McCahon's Last Paintings
}

\author{
REX BUTLER AND LAURENCE SIMMONS
}

\begin{abstract}
In this essay, the authors consider Colin McCahon's so-called Last Paintings, the series of four paintings found in his studio after his death. The status of these works has always been ambiguous. Were they actually completed by McCahon or left abandoned? Are the artistic effects found within them intentional or merely the effect of chance? Against most readings of McCahon, which decide one way or another, the authors try to keep both options open. They attempt to show how this might work with regard to the painting understood to be McCahon's very last, I considered all the acts of oppression (1981).
\end{abstract}

"In a few years, I will be dead. It's chilling to be done now. I can't understand what's happening. I'm not me any more. I am becoming an historic image." (McCahon to Ron O'Reilly) ${ }^{1}$

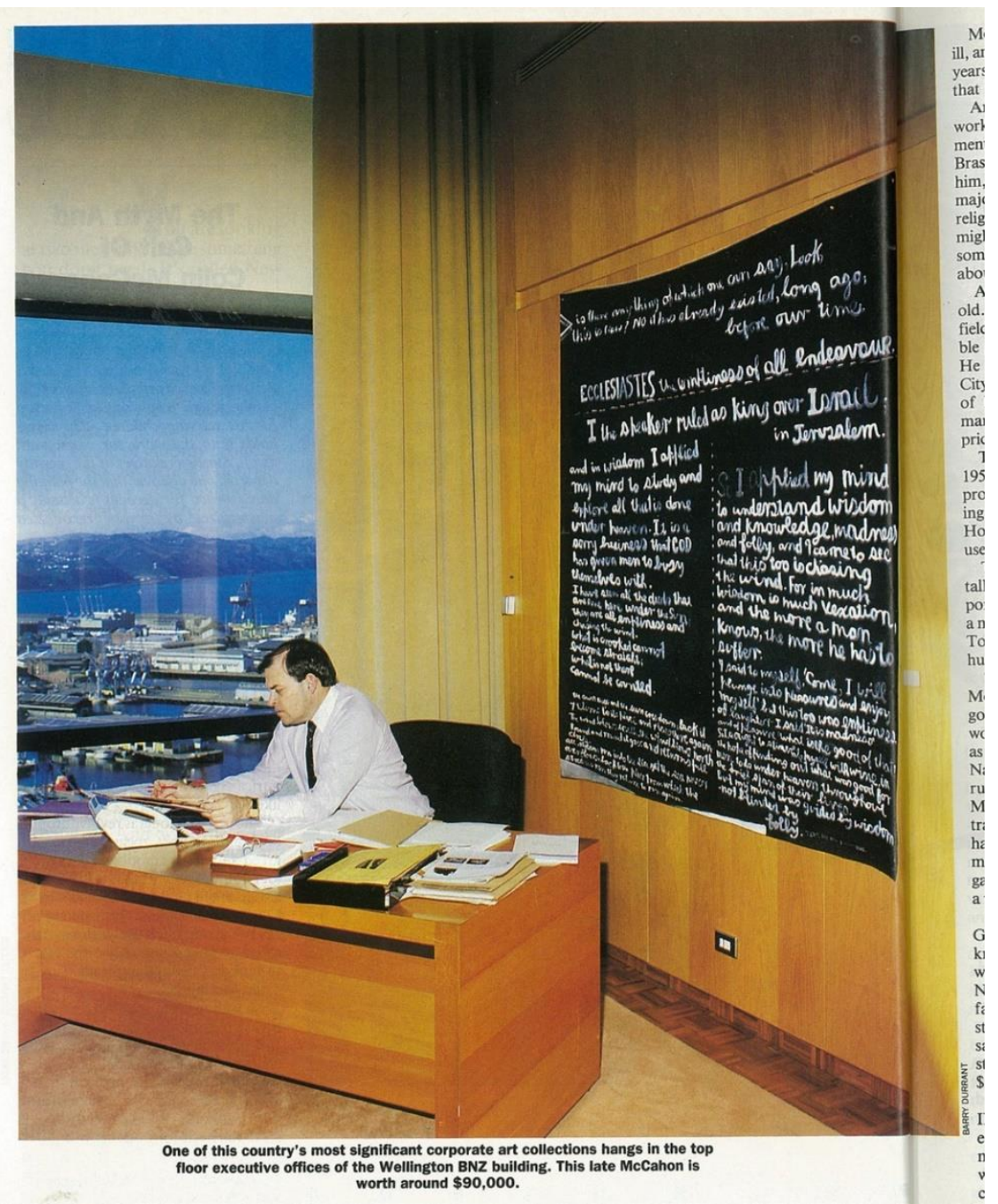

Figure 1. Colin McCahon, Is there anything of which one can say look this is new?, 1982. Hanging in the top floor executive office Bank of New Zealand Building, Wellington (source: North and South, November 1986. Photo credit: Barry Durant). 
Undoubtedly, one of the most interesting photographs ever taken of Colin McCahon's work was reproduced in the November 1986 edition of North and South, not an art magazine but a magazine of lifestyle and current affairs. Taken by photographer Barry Durant, it depicts McCahon's late painting Is there anything of which one can say look this is new? (1982) hanging in the top-floor executive office of the chairperson of the Bank of New Zealand in the Bank's Wellington headquarters.

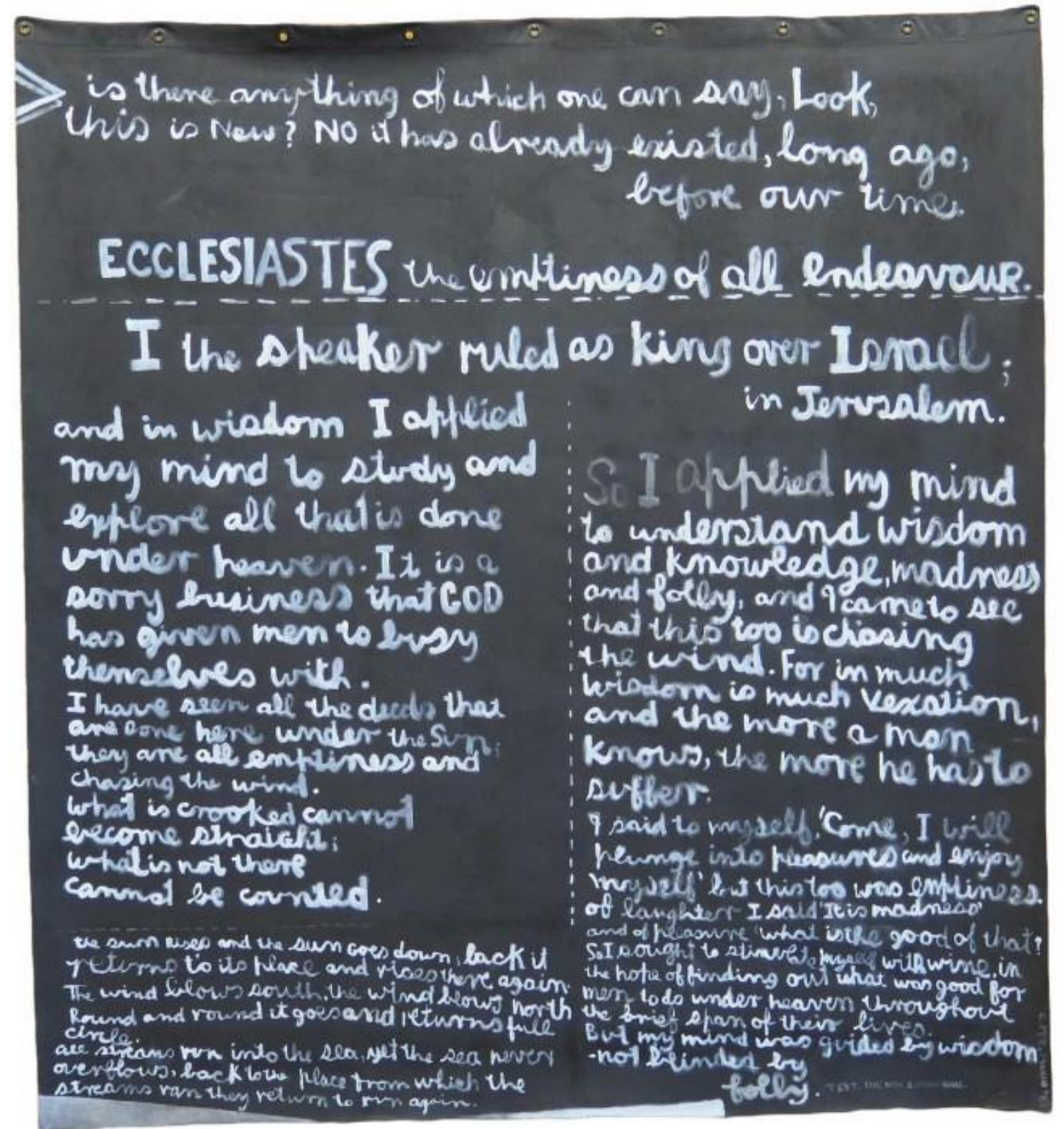

Figure 2. Colin McCahon, Is there anything of which one can say look this is new?, 1982. Synthetic polymers on unstretched canvas, $1955 \times 1810 \mathrm{~mm}$. Bank of New Zealand Collection (courtesy of the Colin McCahon Research and Publication Trust).

Underneath the photograph is a text, part of a longer article praising the Bank's philanthropy, which in typical promotional style lauds the collection as "one of the country's most significant corporate art collections," while incidentally noting that the painting was now worth $\$ 90,000$. The writer of the accompanying article, Rosemary McLeod, declares "McCahon is the 
mythical figure that towers over modern New Zealand art. But no soap opera has as yet devised a character as rich and complex, with a story that follows a simple curve that looks predestined, so symmetrically does it unfold and so profoundly does it serve the need for an art hero."2 And thereafter the bank has continued to promote the work as part of its collection, lending italthough always sure its provenance is acknowledged - to such exhibitions as Colin McCahon: I Will Need Words at the Power Gallery of Contemporary Art, University of Sydney, in 1984; Colin McCahon: Gates and Journeys at the Auckland Art Gallery in 1988; From the BNZ Collection at the City Gallery in Wellington in 1998; and Colin McCahon: A question of faith at the Stedelijk Museum in Amsterdam in 2002. ${ }^{3}$

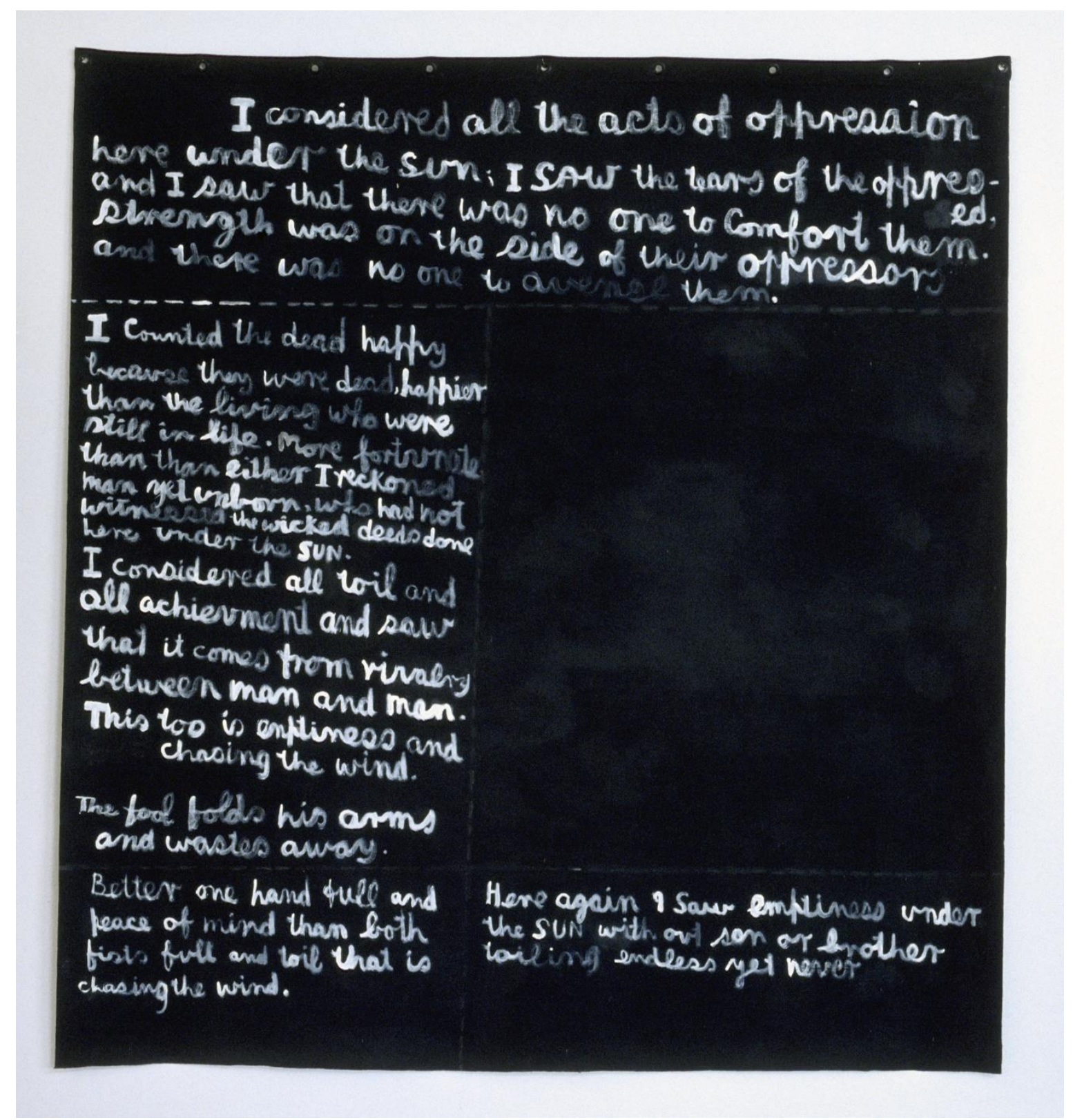

Figure 3. Colin McCahon, I considered all the acts of oppression, 1981. Synthetic polymers on unstretched canvas, $1964 \times 1810 \mathrm{~mm}$. Private collection (courtesy of the Colin McCahon Research and Publication Trust). 
The story of how the painting finds its way into the Bank's collection is an intriguing one. Is there anything of which one can say look this is new? is one of McCahon's so-called Last Paintings, which includes his very last painting, I considered all the acts of oppression, (1981), discovered lying face down in his studio after his death. ${ }^{4}$ McCahon by the time he died had stopped painting for some five years, and had forbidden visitors from going into his studio. It is sometimes suggested that this "giving up" was the effect of years of critical derision and sometimes that it was the effect of Korsakov's syndrome, a genetic condition triggered by years of heavy drinking. According to family and friends, McCahon had slowly declined during this period and had become a shadow of his former self. As his biographer Gordon Brown once famously observed, given that McCahon had always banned it from his house, believing that its endless stream of images would rob him of his ability to create his own, "Near the end of his life when I saw him sitting in front of a television, I realised that the last vestiges of his creative personality had vanished and he had become but a shell of the person I had so affectionately known." McCahon was nursed by his family, especially his wife Anne and daughter Victoria, during these years, increasingly exhibiting signs of dementia and often becoming violent and abusive. He slowly lost all memories of himself, of his achievements and even of the very family that was helping him. There exist several poignant photographs of McCahon in his studio displaying an Elias painting or in an old jumper in his home with a grandchild beside him, looking befuddled and without any sense of recognition.

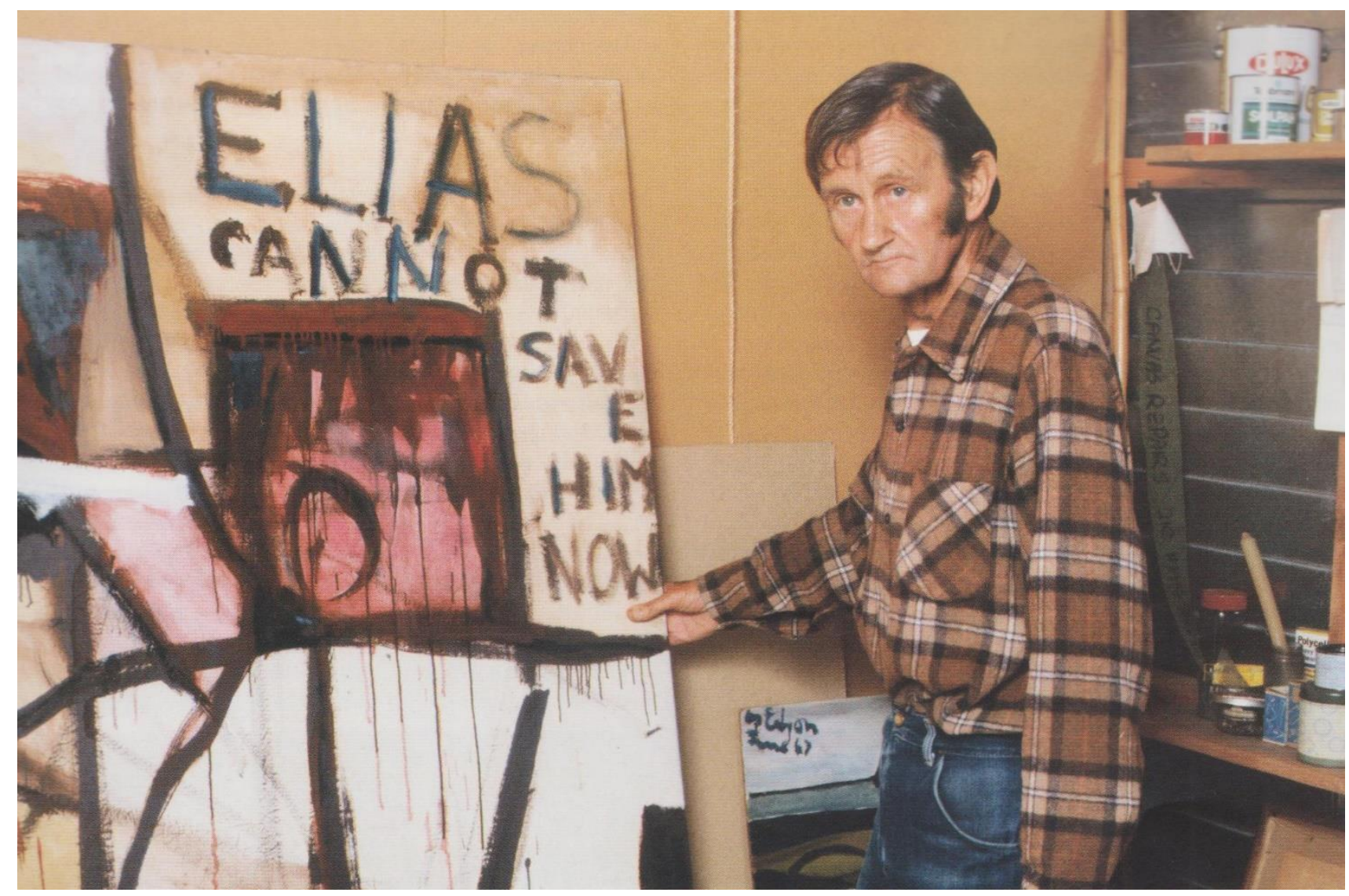

Figure 4. Colin McCahon in his studio, 1982. The image beside him is Elias cannot save him now, 1959 (Photograph courtesy of the Ministry of Foreign Affairs and Trade, Wellington). 
Ironically, it was during these years when McCahon had given up painting and begun to lose touch with reality, when arguably the toll of his long artistic struggle had finally caught up with him, that his reputation and the prices achieved for his works began to rise. At the time, his dealer Peter McLeavey put it like this: "McCahon took all the risks. He paid a price for being under-valued, and a price for being over-valued. His prices now make no impression, he doesn't get any pleasure from them. It has no meaning for him. ${ }^{\prime 6}$ In 1983, at a time when he seemed to have already given up painting, the National Gallery in Wellington acquired one of his greatest and most ambitious works, Practical religion: the resurrection of Lazarus showing Mount Martha (1969) - the complement to the equally large Victory over death 2 (1970), which had been bought and gifted to the National Gallery of Australia-for the then-record price of $\$ 150,000$. In 1984 McCahon's satellite show at the Biennale of Sydney, Colin McCahon: I Will Need Words, cemented his reputation across the Tasman, inspiring Australian admirers. And in 1986, the Director of the Dowse Art Museum in the Lower Hutt, James Mack, knowing that McCahon had stopped painting, and, perhaps taking into account the possibility of his imminent death, organised the exhibition Colin McCahon-A Celebration, which featured mainly his early works.

It is perhaps some comfort, then, to think that when McCahon did eventually die in 1987 his family, after a lifetime of sacrifice and suffering for their husband and father, would finally get their just reward with his now valuable estate. The incongruity was that it was all of the unsold paintings that McCahon had made, the fact that throughout his career taste had not quite caught up with him, that made them now available at a considerably higher price. This, with the greatest of luck, was what an unsuperannuated artist was able to leave behind to heirs and relatives. Imagine, then, McCahon's family's surprise when in his final will and testament he effectively disinherited them, instead leaving the bulk of his estate as well as his now valuable archive to a series of public galleries and libraries. The will, of course at the time publicly available and much discussed, provided for McCahon's wife Anne to receive all personal chattels other than "all my original art work whether by myself or any other person or persons," and for the Director of the Auckland City Art Gallery to have access to and the choice of any works "as he may want for the collection of such gallery." "In fact-and this is why, for all of its apparent cruelty and indifference, it would not have been such a surprise - this last will and testament was a continuation of the strategy McCahon had long followed while still alive. In the years before he died, while he was still competent but perhaps already with some sense of the illness that was soon to overtake him, McCahon had begun to gift work to major New Zealand institutions. And he did so with a curator's trained eye. To institutions that did not yet have one of his works or only a very partial collection, he gave representative works. Thus to the people of Parihaka Pā, he gave Parihaka triptych (1972), to be held at the Govett-Brewster Art Gallery on their behalf, a work that had originally been commissioned for an exhibition at the Waikato Art Museum, in 1973. To the Dowse Art Museum, he gave Caterpillar landscape (1947) in 1980. To institutions that already had some of his works, he gave others that complemented and rounded out their collections. Thus to the Hocken Library in Dunedin, he gave The Song of the Shining Cuckoo (1974) in 1977, The Wake (1958) in 1978 and John in Canterbury (1959) in 1980, which matched the previous gifts of Otago Harbour (1941) in 1966 and Taieri Mouth (1935) in 1971. And to the Auckland City Gallery, which already had so much of McCahon's work and had done so much to promote his career, he gave The Fourteen Stations of the Cross (1966) in 1981 and The Lark's Song (1969) in 1982, which matched the previous gifts of The illumination of festivals (1954) in 1972, and Easter morning (1950) and Six days in Nelson and Canterbury (1950) in 1979. 
In fact, McCahon's family successfully challenged the will. They were able to argue that McCahon was not so easily able to disinherit them. Indeed, the Auckland City Gallery, not wanting the public relations disaster of the artist who had given them so much leaving his family penniless, quickly conceded. Several works-including a number of the Last Paintings - were returned to his family, others were placed on permanent loan to the Gallery, and McCahon's family has continued to hold copyright in his work. As we have seen, during his lifetime but after he had stopped painting, McCahon's Is there anything? had already been sold to the Bank of New Zealand. But several years after his death, in October 1993, the McCahon Family Trust, both to support members of the family and to subsidise the efforts of the Trust to track down otherwise unknown or undiscovered work and to put together a catalogue raisonné, offered McCahon's I considered all the acts of oppression, the painting found face down on the floor of his studio, for sale at auction, where it obtained $\$ 511,750$ when it was purchased by the prominent New Zealand art patron and collector Dame Jenny Gibbs, and the prices have kept on rising ever since.
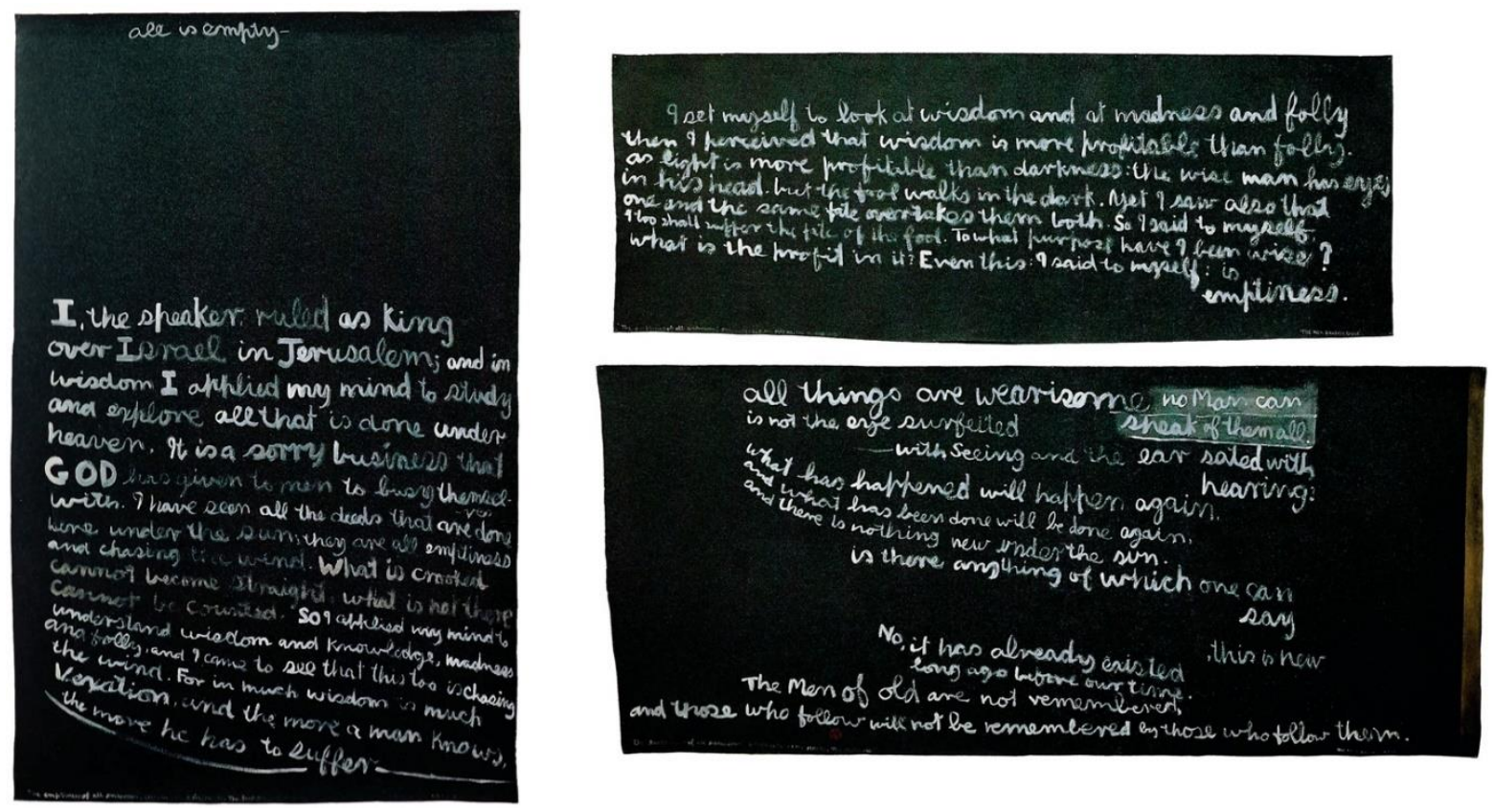

Figure 5. Colin McCahon, The emptiness of all endeavour, 1980. Synthetic polymers on 3 unstretched canvasses, $1815 \times 1190 \mathrm{~mm}, 642 \times 1812 \mathrm{~mm}, 902 \times 2006 \mathrm{~mm}$. Private collection (courtesy of the Colin McCahon Research and Publication Trust).

There are four works in McCahon's Last Painting series in all: The emptiness of all endeavour (1980), Is there anything of which one can say look this is new? (1982), I applied my mind (1982) and I considered all the acts of oppression (1981). And, of course, the first question to be asked is: what exactly is their status within McCahon's oeuvre? After all, insofar as he left one of them face down in his studio and forebade visitors and even family from seeing others of them, the question of what McCahon thought of them or whether he even considered them finished is raised. How was he thinking when he made them? What was his state of mind when he laid arguably the last of them face down? Is the symbolism of the action to be trusted, or was it already an effect of his medical condition or syndrome? Certainly, I considered all the acts of oppression is generally considered to be unfinished, but is this instead an artistic effect? 
(It is undeniably an extraordinarily expressive act, leaving the right-hand side of the canvas unfinished, which is much discussed by the critics, as we will see.) And alongside all of this is the complex question of the dating and internal ordering of the work. In the catalogue for $A$ question of faith, for example, they are dated between 1980 and 1982, which marks the year after which it was thought that McCahon was no longer in control of his faculties, as though that were an end in itself. ${ }^{8}$ In all kinds of ways, these paintings exist on the edge between McCahon's life - his biographical control or intentionality - and the fate or destiny of the work itself.

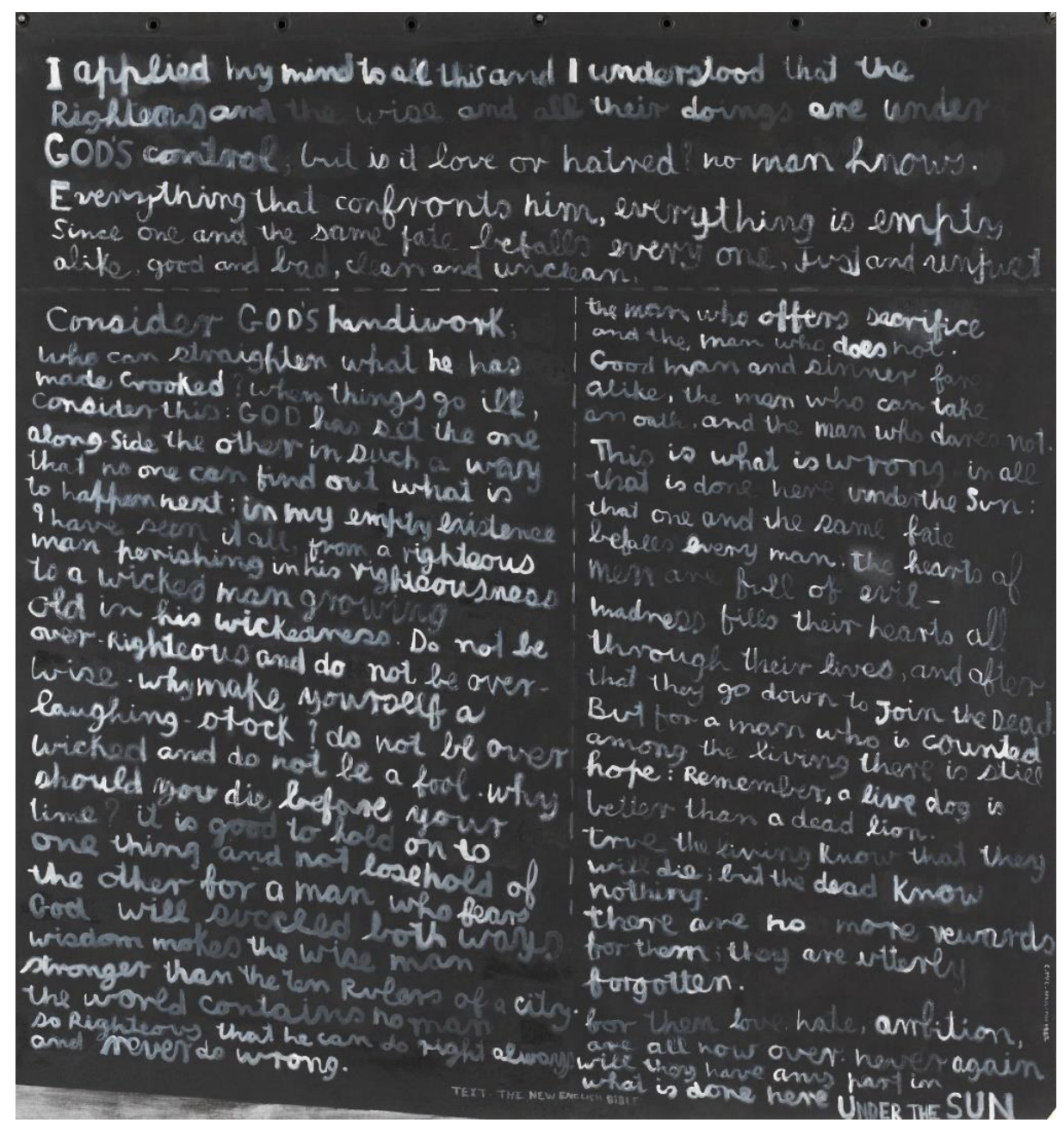

Figure 6. Colin McCahon, I applied my mind, 1982. Synthetic polymers on unstretched canvasses, $1950 \times 1805 \mathrm{~mm}$. National Gallery of Victoria, Australia (courtesy of the Colin McCahon Research and Publication Trust).

At the same time, the temptation to regard these paintings found after his death as part of McCahon's oeuvre must have been overwhelming. The prices paid for his work were constantly rising and McCahon had been a difficult husband and parent, not only during the period of his convalescence but throughout. The bequeathed works, once returned to the family by the Gallery, would have seemed some compensation for the tribulations McCahon had put them all through. And, admittedly, these Last Paintings are perfect examples of what we might call McCahon's late style: pared-down black-and-white renderings of Biblical passages made without accompanying images. It is a style he had arguably been heading towards since The 
Lark's Song, and whose closest equivalent was perhaps the works A Letter to Hebrews (1979) and Paul to Hebrews (1980) of the immediately preceding years. The texts chosen for these Last Paintings were taken from the book of Ecclesiastes, chapters 1, 2, 4, 7 and 9, and to a much greater extent than almost any other of McCahon's series the various passages taken up in the paintings overlap (the only other comparable example is the repeated use of John in the Practical religion series of 1969). ${ }^{9}$ Thus, if it is the line "The emptiness of all endeavour" that gives the work of that name its title, these words are also to be seen in Is there anything? Likewise, the line "I applied my mind" of Is there anything? is also to be found in I considered all the acts of oppression, which as we say is generally regarded as the last painting in the series, not only because it was the one found face down on McCahon's studio after his death but also because its text, taken from Ecclesiastes chapter 4, verses 1, 2-4 and 5-6, is seen to be the most despairing and its right-hand side has been left blank, either as a terminal expression of McCahon's state of mind or as a literal giving up.

So what is it that these Last Paintings are about? And what has been their reception in art history? As we have just indicated, they are largely made up of a series of texts taken from the book of Ecclesiastes. The language of Ecclesiastes requires that it be placed among the later books of the Hebrew canon, although it also exhibits a more "Hellenistic" spirit than any other book of the Bible. The writer of Ecclesiastes is known not by name but by title, Qoholet, which has traditionally been translated into English as "the Preacher." A more accurate translation might be "leader" or "agent of assembly." Some commentators have argued that a qoholet is someone who assembles sentences or proverbs of wisdom (and McCahon was certainly repeating this function). There are four themes that are said to be basic to the thought of Qoholet: human achievement is weak and impermanent; the fate of human beings is uncertain; human beings find it impossible to attain true knowledge of and insight into the world; and the divine goal and imperative of all human endeavor needs to be joy. The critical response to Ecclesiastes is accordingly marked by the contradictoriness of its advice, provoking a range of responses that escapes any simple characterisation. This multivalence may also be explained in part by the fact that it is a text that is full of multiple competing voices (and possibly authors) and an epilogue that was almost certainly written by another hand. ${ }^{10}$ It for these reasons that the interpretation of Ecclesiastes is an ongoing scholarly exercise. The book has been seen as bearing witness to an intellectual crisis in ancient Israel that represents a break with previous thinking. It has been read as a messianic prophecy that demands a new testament and an exercise in negation that emphasises death as a leveller. It has been understood as extolling the vanity of all things and the impossibility of comprehending what God has done. ${ }^{11}$ It has been interpreted alternately as "rigorously hopeless" and "affirming joy." 12 As a way out of this impasse, one commentator proposes that Ecclesiastes's "seeming contradictions are a deliberate teaching tool," but as Martin Luther once shrewdly observed, "This book is one no one has ever completely mastered."13

Along the same lines, what can undoubtedly strike us at first about the paintings based on these texts is their despair. In The emptiness of all endeavour are the lines "It is a sorry business that God has given to men to busy themselves with" (Ecclesiastes 1:13). I applied my mind for its part contains "The hearts of men are full of evil-madness fills their hearts all through their lives" (Ecclesiastes 9:3). And, finally, Is there anything? speaks of the futility both of thinking and of not thinking about the problems of the world: "So I applied my mind and understood wisdom and knowledge, madness and folly, and I came to see that this too is chasing the wind" (Ecclesiastes 1:17). And all of this undoubtedly seems to fit a certain autobiographical reading of the works - and attempts to consider them a kind of "last" word - as though they effectively reflected McCahon's own beleaguered state of mind at the time he made them. That is to say, 
the Last Paintings would not only represent McCahon's giving up of painting, but also be about McCahon's giving up of painting. Francis Pound, for example, argues that "Now it seems the cause was hopeless, and painting insufficient for the purpose." 14 And this sentiment is echoed by Gordon Brown, who writes of the paintings as "the musings of a man spiritually fading . . . the chatter of a man caught in his illness becoming aware that his psyche but not his body is dying." "It is an attitude echoed by such later commentators as Peter Simpson, who contends "In these words the tragic vision is scarcely relieved by any light of hope." Marja Bloem and Martin Browne write in the Stedelijk Museum Bulletin for McCahon's retrospective there that "[McCahon's] attitude evolved from a positive outlook, through a period of doubt, to a feeling of utter despair. For him, finally, there was no certainty of the reward previously thought to have been promised in the afterlife." 17

And yet, just as insistently, writers on McCahon have wanted to see in this late work some continuing cause for optimism. Pound in his "Endless Yet Never: Death, Prophecy and McCahon's Last Painting," originally written for an exhibition held prior to the sale of $I$ considered all the acts of oppression in 1993, admits at first that McCahon's Last Paintings appear largely pessimistic. As he says of that section left uncompleted in I considered all the acts: "In the Last [Painting], even that silver [of the others] is gone. What had been once a dark sky with star-like words and the emptied-out field of modernist painting has become nothing but black." But then, towards the end of his essay - and undoubtedly the circumstances of it being up for auction in part explain this-Pound argues that the very desire by McCahon to communicate this despair is evidence of a continued hope, that the very act of communicating this pessimism is its overcoming: "And yet, in a sense, the very act of painting these texts is a positive one, an act that runs counter to the utter despair of which the text speaks." 18 Similarly, Brown in "A Painter's Pleasure," originally given as the opening address for the exhibition An Occasion for Celebration at Te Manawa Art Museum in Palmerston North in 2003 - and, again, the circumstances explain something of his approach-proposes that the Biblical text on which McCahon bases the series is not entirely negative. Tellingly, however, he does this with reference not to anything McCahon actually wrote on the Last Paintings, but to notes McCahon put together for his Survey Exhibition at the Auckland City Gallery in 1972, some ten years before he made the Last Paintings and when arguably his state of mind was different. As Brown writes there, "Those people who over-emphasise the grim and gloomy aspects of Ecclesiastes should reassess their negative attitude towards this short book and let some of the exuberance of the text shine through in equal measure to the nails driven home, piercing flesh and conscience." 19

How, then, are we to see these Last Paintings? In what sense can we understand them as still relevant to us? In fact, the first point to make about them is that they do not simply constitute a final word. They offer no form of summary of or Last Judgement upon the world. They put forward no kind of a weighing up of positives and negatives before reaching some final verdict (despite McCahon sometimes structuring his canvases in this way by dividing them up into left- and right-handed sides). In this sense, they are neither simply pessimistic nor optimisticand, in fact, we can see both interpretations as a reaction to or an attempt to cover over the work's refusal to declare their intention in this way. And again in this regard McCahon is true to the tone and logic of the book of Ecclesiastes he uses as his source, for one of the oftremarked themes of the book is the inability of humans to seize and hold, to take final possession of, a thing. ${ }^{20}$ For example, in Is there anything? not only are "all deeds done under the sun" empty, but so is every attempt to "apply one's mind to understand wickedness and knowledge, madness and folly." It is a sentiment repeated in the "all is empty" and "To what purpose have I been wise?" of The emptiness of all endeavour. Once more, the argument of I 
applied my mind is the idea that both alternatives facing us - "the man who offers sacrifice and the man who does not" - end up the same. Finally, in I considered all the acts of oppression, McCahon explicitly rejects the idea of any final redemption, any Last Judgement that would redeem past suffering by making it meaningful: "I saw the tears of the oppressed and I saw that there was no one to comfort them. Strength was on the side of the oppressors and there was no one to avenge them."

But we would also say along the same lines, again against most if not all readings of them, that these Last Paintings are not simply prophetic in any obvious sense. That is, McCahon does not in or through his work in any way stand above or exempt himself from the situation he is diagnosing. He is not offering any superior wisdom, and it is not even through the representation of his despair that McCahon would transcend it. ${ }^{21}$ Of course, at first sight it is tempting with regard to a work like Is there anything? to suggest that it offers some kind of a commentary on its own final destiny, sitting up high in the chairperson's office of the Bank of New Zealand. Such words in its text as "the emptiness of all endeavour," "what is crooked cannot become straight" and "what is not there cannot be counted" appear at least to offer the possibility of being read ironically, as though even if the painting is materially compromised, in some other "spiritual" dimension it is ultimately uncompromised. It would be as though its true meaning would lie not in what it now means (an embodiment of cultural prestige) but where it is speaking from (an empty and otherworldly place of enunciation). It would be as though, regardless of how its external circumstances might change, there is nevertheless some essential and unchanging message that it delivers. (This again would seem to be the underlying message of "Is there anything of which one can say, Look, this is new?": that it is some eternal truth that Christ transmits that does not change as the unending follies of humankind also do not change.) And all of this would correspond to everything we have previously said about McCahon's efforts to guarantee himself an afterlife, both through the actual donation of his paintings to institutions and through the "prophetic" nature of his work, as though it is somehow about the events that will happen to it, as though McCahon, or at least his work, could predict the future and in some way bring it about.

However, we would propose that, if the Last Paintings stand for anything - and this is also the retrospective light they cast on the rest of McCahon's oeuvre-it is the rejection of this conception of themselves. Precisely their first gesture is to forsake any external viewpoint onto things or Last Judgement that would redeem the cruelties and injustices of which they speak. They would do away with the guarantee and perhaps even the possibility of any spiritual or artistic afterlife. This is the meaning of those words of lamentation at the bottom right-hand side of The emptiness of all endeavour from Ecclesiastes 1:11: "The men of old are not remembered and those who follow will not be remembered by those who follow them." And the distinction is made clearer when we compare this to the words from A Letter to Hebrews (11:2) in McCahon's earlier A Letter to Hebrews (Rain in Northland) (1979), which state "It is for faith that the men of old stand on record." This again would be the obvious meaning of McCahon seemingly giving up on his work in the right-hand side panel of I considered all the acts of oppression: the collapse of any outside speaking position-the "blankness" or "openness" of the afterlife - back into the work. It would be to suggest that there is no ulterior destiny for the work beyond the time of the work itself, no "inner" principle that is not subject to material constraint, so that it would survive all setbacks and transform all failures into a wider story of success. This future is now only within the work itself, subject to all of its worldly contingencies and vicissitudes. There is no place outside of history from where we might remember all the "men of old" who went before us, but only the pure unmarked immanence of its progression. 
Except that, in the case of I considered all the acts of oppression-but we would want to say that this is true in a way of everything McCahon does-all of this takes place within the work. It is what the work depicts, what it is about. This we might say is the ambiguous status of that empty black square there: it is at once where the painting passes out into the contingencies of the world and where all of the world comes to be inside the painting. And it is this that gives McCahon's work, again true to its source in Ecclesiastes, its specific prophetic status. It is not that it puts forward some particular prediction in advance, to which the world either will or will not confirm, but that it simply remarks the world as it is, to which the world can only conform. For let us go back to that statement we recently considered in another of the Last Paintings. It comes from the right-hand side of The emptiness of all endeavour: "The men of old are not remembered and those who follow will not be remembered by those who follow them." And we find something similar in the right-hand side of I applied my mind: "[The dead] are utterly forgotten. For them love, hate, ambition, are all now over." It is not that these works constitute some exception to this or point to some place outside of it - for, as we have tried to make clear, McCahon is speaking as much as anything of himself here-but in saying that the men of old will not be remembered, that the dead will be forgotten, we necessarily also remember them. It is not so much that the work is simply outside what it speaks of as that there is an endless passage or movement between the inside and the outside of the work. And this is to say that it is just because the work does not exempt itself from what it speaks of that what it says applies to everything.

Or think again about the endless debate over whether the leaving of that square to the right of I considered all the acts of oppression is deliberate or accidental. Of course, in one way, as has recently been pointed out, it can appear as though that blank square is an intended artistic effect, as though that line from Ecclesiastes 1:6 beneath it- "Here again I saw an emptiness under the sun"- brilliantly and evocatively refers to it. ${ }^{22}$ And this is undoubtedly true. But the reason for this is that, in its very openness and unfinishedness, anything can refer to the work or the work can refer to anything. That is to say, if in one way that phrase "emptiness under the sun" can appear to be referring to the blank space above it, in another it is just this blank space that gives the phrase its meaning. Just as it is the white lettering of the "sun" that allows that black or blankness to be seen, so it is also this blackness or blankness against which the "sun" is seen. ${ }^{23}$ All this is why we have of late begun to wonder how we might think I considered all the acts of oppression in the light of the recent Black Lives Matter protests in America and elsewhere. It is not just the title of McCahon's work and its words, but the fact that that its blackness is a certain opening up to a future that is not his to know and that he passes over to others to make of it what they will. McCahon towards the end of his life was certainly a supporter of Māori culture and Land Rights, but this does not exhaust the potential of the work, the way there is always something else to think, just as Black Lives Matter aims at something even more universal than All Lives Matter.

It is all this, to conclude, that we might mean by speaking of the Last Paintings constituting a "late style" in the sense that someone like Edward Said spoke of it. In Said's On Late Style, he points to the way that certain great artists at the end of their careers, after all of the struggle of trying to create a recognisable manner, give this up in producing work that is effectively styleless, with no obvious defining qualities. (Indeed, one of the implications of Said's argument is that all of the late styles he speaks of are comparable, that there is something like a universal late style or that each late style seeks to be universal.) Thus Shakespeare writes the ambiguous and emotionally subdued The Tempest and A Winter's Tale after the comedies and tragedies. Beethoven writes the introspective, compositionally unformed and almost 
improvised piano sonatas. Thomas Mann writes Doctor Faustus, his cautionary tale about unchecked artistic ambition that ends in madness and despair. And Said's point is that, against the usual humanist clichés, great art lives on - this is what the truth of late style points to - not through the transmission of eternal human vérités, which inevitably exhaust themselves, reveal themselves to be too specific, too much of their time, but because it is open, contingent, unfinished. As Said writes, "Beethoven's late works remain unco-opted by a higher synthesis: they do not fit any scheme, and they cannot be reconciled or resolved, since their irresolution and fragmentariness are constitutive, neither ornamental nor symbolic of something else. The late works are about 'lost totality,' and it is in this sense that they are catastrophic."24

This is also what we see in the late McCahon. To the extent possible, he wants to empty his art of all positive qualities in an act of artistic stripping back or religious kenosis until it is almost nothing or blank. The work does not propose anything positive, does not predict anything specific, but simply remarks what is. But it is at this point that everything is now explained by it or it is the secret explanation of everything in a perfect act of prophecy that never comes to an end. It is exactly like - and this again is like the meaning of God in Ecclesiastes - God never arrives in any Second Coming, but His absence can only be thought through Him. The very absence of God can now only be explained because of God Himself, just as McCahon's work lives on in its absence or blankness. "Endless but never" are arguably the last words McCahon ever wrote, down at the bottom right-hand corner of I considered all the acts of oppression, taking the place of the artist's signature. And this expression is always different and always the same. It is proven or validated only in being repeated, is never just one but always split or divided, signed or countersigned by another, even if it is the same as the one who originally signed it. ${ }^{25}$ (It is the same way in which we can never simply copy our own signature.) And all of this is true of McCahon's paintings, which exist for the first time only in being embodied by their spectator, who sees in them what McCahon could never possibly have intended. But can we be sure of that? For as McCahon says in I applied my mind, "In my empty existence I have seen it all."

\footnotetext{
${ }^{1}$ Undated letter, received 10 February 1979, cited in William McAloon, "Where is Uncle Frank? McCahon's Late Works and A question of faith," in Colin McCahon: A question of faith: Papers from a Seminar, ed. Roger Taberner (Auckland: Auckland City Art Gallery, 2003), 63.

${ }^{2}$ Rosemary McLeod, "The State of New Zealand Art," North and South (November 1986): 46. ${ }^{3}$ The painting was first shown in the exhibition Two Recent Paintings by Colin McCahon, Peter McLeavey Gallery, 12 April-1 May 1983, and was for sale for $\$ 9,000$.

${ }^{4}$ William McCahon describes this as follows: "On the day of Colin's death, my sister and I felt compelled to clean his studio. ... As we cleaned the studio we found the painting I considered all acts of oppression [sic], symbolically face down on the floor. It was such a personal and conscious statement from Colin to his audience that we hung it on the wall of St Joseph's Church in Grey Lynn during his funeral" ("Introduction," in Colin McCahon: The Last Painting (Auckland: Peter Webb Galleries, 1993), 2.

${ }^{5}$ Gordon H. Brown, Towards A Promised Land: On the Life and Art of Colin McCahon (Auckland: Auckland University Press, 2010), 4.

${ }^{6}$ Cited in McLeod, "The State of New Zealand Art," 49.

${ }^{7}$ The full clause (3 [ii]) of McCahon's will reads: "As to all my original art work whether by myself or any other person or persons to allow my said wife to have the use and enjoyment thereof during her life and from and after the death of my said wife or from and after my death if she shall predecease me to allow the Director of the Auckland City Art Gallery to chose one or more thereof as he may
} 
want for the collection of such gallery such choice to made within two months of the receipt of written notification to such Director from my trustees of this provision of my will AND any of the said works not chosen by the said Director shall be held by my trustees for such child or children of mine as shall at the death of my said wife or at my death if she shall predecease me be living and shall have attained or shall live to attain the age of twenty years AND if more than one as tenants-incommon equally between them" (Archives NZ Reference and record no. BA22 1570 BOX4077 2262/1987).

${ }^{8}$ For his part, Brown writes, "Despite the dates McCahon gave to some of these works, all were begun and, to the greatest extent, completed in 1980" (Towards A Promised Land, 180).

${ }^{9}$ It is perhaps also a sign of McCahon's diminished mental capacity that he was only able to work with such a small selection from the Bible.

${ }^{10} \mathrm{~T}$. A. Perry has argued for a literary reading of Ecclesiastes in which the text is to be approached as a dialogue between two figures, and this dialogical approach allows us to understand the "contradictions" that appear to have plagued commentators. See his Dialogues with Koheleth: The Book of Ecclesiastes. Translation and Commentary (Philadelphia: Pennsylvania State University, 1993).

${ }^{11}$ The word hebel occurs 38 times in Ecclesiastes. However, despite this visibility, its meaning is not clear. The different English versions of its first appearance translate the term variously as "vanity of vanities" (Authorised Version), "emptiness, emptiness" (New English Bible, which McCahon used) and "meaningless, meaningless" (New Living Translation).

${ }^{12}$ Roger Whybray, Ecclesiastes: Based on the Revised Standard Version (Grand Rapids, Michigan: Eerdmans, 1989).

See Dermot Cox, "Ecclesiastes," in The Oxford Companion to the Bible, ed. Bruce Metzger and Michael D. Coogan (Oxford: Oxford University Press, 1993), 177.

${ }^{13}$ Martin Luther, "Notes on Ecclesiastes" [1532], Luther's Works, ed. J. Pelikan (St Louis: Concordia, 1972), vol. 15, 7.

${ }^{14}$ Francis Pound, "Endless Yet Never: Death, Prophecy and McCahon's Last Painting," in Colin McCahon: A question of faith, ed. Marja Bloem and Martin Browne (Nelson: Craig Potton Publishing, 2002), 62.

${ }^{15}$ Gordon H. Brown, “"The Speaker,' The Painter, The Discursive Dialoguer," in Colin McCahon: The Last Painting, 16.

${ }^{16}$ Peter Simpson, Answering Hark: McCahon/Caselberg, Painter/Poet (Nelson: Craig Potton Publishing, 2001), 122, fn. 296.

${ }^{17}$ Marja Bloem and Martin Browne, "Colin McCahon," Stedelijk Museum Bulletin 5 (May 2002): 3.

${ }^{18}$ Pound, "Endless Yet Never," 57, 62.

${ }^{19}$ Brown, Towards A Promised Land, 49.

${ }^{20}$ See on this Craig Bartholemew, "Qoheleth in the Canon?: Current Trends in the Interpretation of Ecclesiastes," Themelios 24, no. 3 (June 1999): 4-20.

${ }^{21}$ William McAloon will make something like this point in his critique of Pound's insistence on McCahon's "lifelong use of the prophetic voice" and "adoption of the voice of prophetic suffering." As he will write particularly with regard to the Last Paintings, "Apart from the obvious fact that it belongs to the Wisdom literature, Ecclesiastes is perhaps the least prophetic of all the books of the Old Testament" ("Where is Uncle Frank," 77, fn. 6).

${ }^{22}$ See on this Dame Jenny Gibbs's essay on I considered all the acts of oppression for the McCahon House 100 website (https://mccahonhouse.org.nz/100/dame-jenny-gibbs/).

${ }^{23}$ It is in this sense - and this has been implicit in everything we have been saying throughout - that we might say that that black square to the right of I considered all the acts of oppression is split: it both is and is about itself at the same time. In this regard, we might compare it to that "AM" painted black on black before the "I AM" of Victory over death 2 (1970) and even to Malevich's Black Square (1913).

${ }^{24}$ Edward Said, "Thoughts on Late Style," Times Literary Supplement 26, no. 15 (August 2004): 2-3. See more generally Edward Said, On Late Style: Music and Literature Against the Grain (New York: 
Pantheon, 2006). See also Carel Blotkamp, The End: Artists' Late and Last Works (London: Reaktion, 2019).

${ }^{25}$ Here we might trace all of the ways in which the phrase "Endless Yet Never" has been taken up and repeated not just by Biblical scholars but also writers on McCahon. We might think, for example, of Pound's "Endless Yet Never: Death, Prophecy and McCahon's Last Painting," and the short biography by Martin Edmond, Colin McCahon: Endless Yet Never (Titirangi, Auckland: McCahon House, 2020), but also of the work of the Australian Biblical scholar Zoe Alderton in the chapter "The Final Warnings," in The Spirit of Colin McCahon (Newcastle upon Tyne: Cambridge Scholars, 2015), 294-323. 